\title{
Changes in the properties of $\mathrm{Cu}-\mathrm{Al}-\mathrm{Mn}$ shape memory alloy due to quaternary addition of different elements
}

\author{
Pravir Kumar $^{1}$, Ashish Kumar Jain ${ }^{1}$, Shahadat Hussain ${ }^{1}$ \\ Abhishek Pandey ${ }^{1}$, Rupa Dasgupta ${ }^{1}$
}

\begin{abstract}
${ }^{1}$ CSIR-AMPRI, Bhopal, Madhya Pradesh, INDIA - 462026
e-mail: dasguptarupa@gmail.com, pravirkumar30@gmail.com, ashishjain.bm@gmail.com, shahadat_ind@yahoo.com, pande2431@gmail.com;
\end{abstract}

\begin{abstract}
Advantages of $\mathrm{Cu}$ based shape memory alloy include amongst other features, high transformation temperature, low cost of production, ease in manufacturing processes and ability to vary the achieved properties through alloying additions. It has been often reported that these alloys are very sensitive to the alloying additions in terms of properties achieved and phase precipitation necessary for development of shape memory properties. This behaviour in $\mathrm{Cu}$ based shape memory alloys i.e. being very sensitive to its constituents can be used positively to design alloys with pre set properties if the alloying additions and their percentages are properly controlled.

In an attempt to understand the effect of different alloying additions, $2 \%$ of different elements [Zn, $\mathrm{Si}$, $\mathrm{Mg} \& \mathrm{Cr}$ ] were added to a known $\mathrm{Cu}$-based shape memory alloy [Cu-12.5 wt\% of Al-5 wt \% of $\mathrm{Mn}]$. The objective was to ascertain changes or improvements achieved due to the additions in terms of microstructural changes, hardness, phase precipitation and transformation temperatures. Attempts have been made to analyze the changes in properties achieved in the base $\mathrm{Cu}-\mathrm{Al}-\mathrm{Mn}$ alloys due to the quaternary additions. Grain structure with $\alpha+\beta$ phases, which is a pre requisite for martensite formation on quenching is seen in all the alloys indicating that all the alloys have potential to exhibit the shape memory behaviour. The martensite formation with different morphologies is observed in the quenched samples however. XRD results have identified the precipitated phases to be the martensitic phases. The DSC results indicate clear transformation peaks in most of the samples with significantly high transformation temperatures. The findings confirm the variation in properties achieved due to different additions and improvements achieved in terms of higher transformation temperatures and martensite formation due to the alloying additions. An attempt has been made to understand the findings.
\end{abstract}

Keywords: Shape memory alloys, transition temperature, martensite, X-ray diffraction studies, phase precipitation

\section{INTRODUCTION}

The main advantage of $\mathrm{Cu}$ based shape memory alloy which has triggered a wide range of investigation and research work in the field of shape memory effects are its possibility of high transformation temperature, low cost of production and ease in manufacturing processes. Among the $\mathrm{Cu}$ based shape memory alloys mostly investigated, the $\mathrm{Cu}-\mathrm{Al}-\mathrm{Ni}$ [1-7], $\mathrm{Cu}-\mathrm{Al}-\mathrm{Zn}$ [요밀 extensively. But most $\mathrm{Cu}-\mathrm{Al}-\mathrm{Ni}$ and $\mathrm{Cu}-\mathrm{Zn}-\mathrm{Al}$ polycrystalline shape memory alloys are brittle and cannot therefore be cold worked. Attempts to improve the ductility of these polycrystalline $\mathrm{Cu}$ based shape memory alloys by grain refinement have only resulted in limited success. However, it has been reported in recent studies that $\mathrm{Cu}-\mathrm{Al}-\mathrm{Mn}$ alloys with low aluminum contents show excellent ductility because their parent phase with L2 structure possesses comparatively a lower degree of order [21, 22]. This feature could well be useful for the shape memory alloys to exhibit better pseudoelasticity. It has been reported that alloying additions play a very significant role in the properties of $\mathrm{Cu}$-based shape memory alloys and pre requisite properties can be achieved by proper designing/selection of the alloying elements.

The main objective of present work is to determine the effect of alloying a known Cu-based SMA alloy [13-16, 19] namely $\mathrm{Cu}-12.5 \mathrm{Al}-5 \mathrm{Mn}$ alloy with four different alloying additions, through changes or 
improvements achieved due to the additions in terms of microstructure, hardness, phase precipitation and transformation temperatures. Attempts have been made to analyse the changes in properties achieved in the base $\mathrm{Cu}-\mathrm{Al}-\mathrm{Mn}$ alloys due to the quaternary additions.

\section{MATERIALS AND METHODS}

Four different alloying elements were added to the base alloy as $\mathrm{Cu}-12.5 \mathrm{wt} \% \mathrm{Al}-5 \mathrm{wt} \% \mathrm{Mn}-2 \mathrm{wt} \% \mathrm{X}[\mathrm{X}=\mathrm{Zn}$, $\mathrm{Si}, \mathrm{Mg}, \mathrm{Cr}$. The samples were prepared through liquid metallurgy route using gravity die in the as cast conditioning. Pure copper, aluminum, manganese and the respective quaternary alloying element were taken in right quantities to weigh $1000 \mathrm{~g}$ of the alloy in total and were melted together. Molten alloys were poured in graphite mould to get in the as cast conditionings in cylindrical shape of $12 \mathrm{~mm}$ diameters and $150 \mathrm{~mm}$ length.

Samples from the cast alloys were chemically analysed using optical emission spectroscope; Bruker Make OES Model No. 4549 Q4 TASMAN.

Samples from the in the as cast condition alloys were subject to homogenization treatment at $473 \mathrm{~K}$ for 2 hours in a muffle furnace and furnace cooled. Samples from the homogenized alloys were heated and held for $2 \mathrm{hrs}$ at $1193 \mathrm{~K}$ followed by ice quenching in an attempt to precipitate the martensitic structure.

The homogenised and quenched samples were polished metallographically using an automatic polishing machine capable of polishing six samples together (Buehler make, Model EcoMet 3000) using standard procedures. The microstructure was observed in an optical microscope (LEICA make, Model LEICA DM 6000M and Metalloplan) and FESEM (FEI make, Model Nova Nano SEM 430) were optical micrographs were not properly resolved.

XRD of polycrystalline samples was done using X-Ray Diffractometer [Make:Bruker Model:D8 Advanced] with $\mathrm{CuK} \alpha$ radiation to identify the phases present in the samples at room temperature.

Differential Scanning Calorimetric studies were carried out on quenched samples using a Differential Scanning Calorimeter [Mettler Toledo make, Model DSC1 STAR ${ }^{\mathrm{e}}$ SYSTEM] Approximately 8 to $9 \mathrm{mg}$ of powder sample was used which was scrapped from the quenched samples. Tests were carried out in two steps to identify transformation at low and high temperatures; from $-10^{\circ} \mathrm{C}$ to $200{ }^{\circ} \mathrm{C}$ and room temperature to $550^{\circ} \mathrm{C}$ maintaining a constant rate of $10^{\circ} \mathrm{C} / \mathrm{min}$.

The hardness of samples was determined on metallographically polished samples using Vicker's hardness tester (K.B. Pruiftechnik, Model No. KB250BVRZ) applying a load of $5 \mathrm{~kg}$. An average of at least seven readings was taken at different portions of the sample for reporting.

\section{RESULTS AND DISCUSSION}

The chemical composition of the samples is tabulated in Table 1; it shows no much variation in composition from the proposed compositions. The base alloy is $\mathrm{Cu}-12.5 \mathrm{Al}-5 \mathrm{Mn}$ [marked $\mathrm{A}$ ] and with additions marked $\mathrm{A}-\mathrm{Zn}, \mathrm{A}-\mathrm{Si} . .$. and the like depending on additional the alloying element $[\mathrm{X}=\mathrm{Zn}, \mathrm{Si}, \mathrm{Mg}$ and $\mathrm{Cr}]$.

Table 1: Chemical composition

\begin{tabular}{c|l|c|c|c|c|c|c|c|c}
\hline $\begin{array}{c}\text { DESIG- } \\
\text { NATION }\end{array}$ & $\begin{array}{l}\text { PROPOSED } \\
\text { COMPOSITION }\end{array}$ & Cu & Al & Mn & Ni & Zn & Si & Mg & Cr \\
\hline $\mathrm{A}$ & $\mathrm{Cu}-12.5 \mathrm{Al}-5 \mathrm{Mn}$ & Rem. & 12.27 & 3.60 & 0.012 & 0.161 & - & - & - \\
\hline $\mathrm{A}-\mathrm{Zn}$ & $\mathrm{Cu}-12.5 \mathrm{Al}-5 \mathrm{Mn}-2 \mathrm{Zn}$ & Rem. & 12.02 & 4.84 & - & 2.18 & - & - & - \\
\hline $\mathrm{A}-\mathrm{Si}$ & $\mathrm{Cu}-12.5 \mathrm{Al}-5 \mathrm{Mn}-2 \mathrm{Si}$ & Rem. & 11.92 & 4.82 & - & - & 1.96 & - & - \\
\hline $\mathrm{A}-\mathrm{Mg}$ & $\mathrm{Cu}-12.5 \mathrm{Al}-5 \mathrm{Mn}-2 \mathrm{Mg}$ & Rem. & 11.85 & 4.63 & & - & - & 2.44 & - \\
\hline $\mathrm{A}-\mathrm{Cr}$ & $\mathrm{Cu}-12.5 \mathrm{Al}-5 \mathrm{Mn}-2 \mathrm{Cr}$ & Rem. & 12.12 & 4.22 & - & - & - & - & 1.85 \\
\hline
\end{tabular}

The optical micrographs of the samples in the homogenised and quenched conditions are shown respectively in Figure 1. In alloys where the microstructure could not be resolved in the optical micrographs, FESEM micrographs have been given in an attempt to get better resolution. 
Grain structure with $\alpha+\beta$ phases is visible in the homogenised condition of all the alloys; which is a pre requisite for martensite formation on quenching [7]. This clearly indicates that all the alloys have potential to exhibit the shape memory behaviour. Precipitation in the grains typical of shape memory alloys is also seen in all the alloys including the base alloy. There is a large variation in the grain size; however, presence of any particular element cannot be said to affect the grain size. Uniformity in grain sizes has been brought about by homogenization as seen from the micrographs which show the variation in grain size is significantly less [mostly uniform] in the homogenised samples inspite of its variation between alloys.

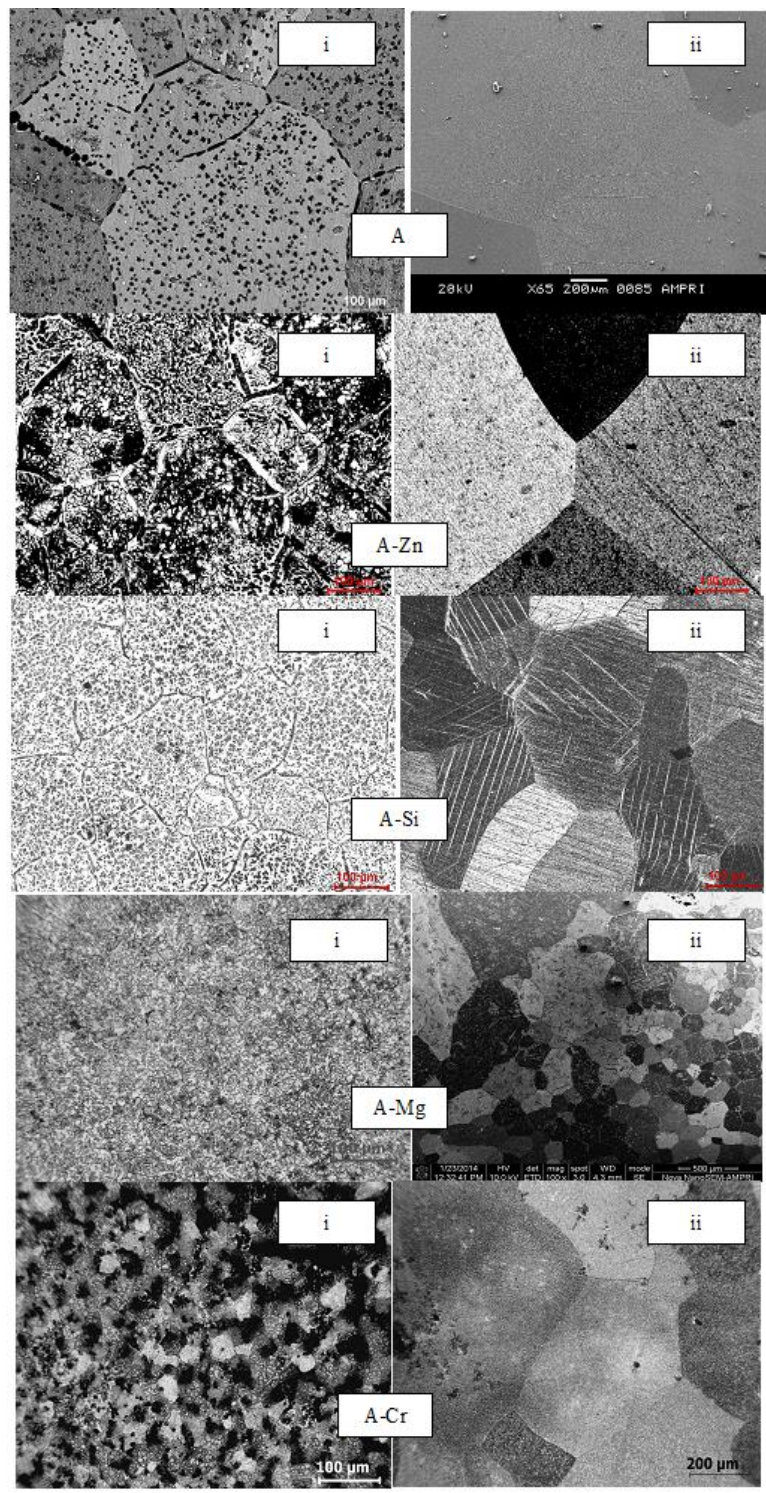

Figure 1: Microstructure of Samples in [i] homogenised and [ii] quenched conditions

Quenching from high temperatures was carried out expecting to precipitate the martensitic phases. The martensite formation is not marked in all the quenched samples like addition of $\mathrm{Zn}$ and $\mathrm{Cr}$, the granular structure is maintained even in the quenched condition; the microstructures of these samples are not well resolved even in the FESEM micrographs. Addition of $\mathrm{Si}$ and $\mathrm{Mg}$ though retains the granular structure on quenching but heavy precipitation is seen in the quenched samples indicating possible martensite formation. The plate- or spear-like martensite [the zig-zag $\beta^{\prime}$ phase] is observed where the martensitic structures are observed.

The X-ray diffraction pattern of the in the as cast condition and quenched samples of the base alloy [marked A] alongwith the patterns of the quenched samples of the other compositions are plotted in Figure 2. The major probable peaks identified have been identified and marked in the figure. The same has also been tabulated in Table 2. $\mathrm{Cu}$ is expectedly the major phase precipitated in all the samples; alongwith phases 
related to $\mathrm{Al}$ and $\mathrm{Cu}$ mainly. The martensitic phases of $\mathrm{Al}_{2} \mathrm{Cu}_{3}\left[\beta^{\prime}\right], \mathrm{Al}_{4} \mathrm{Cu}_{9}\left[\gamma^{\prime}\right]$ and $\mathrm{Cu}-\mathrm{Zn}$ have been clearly identified. In some samples only martensitic phases have been identified in the quenched condition signifying perhaps completion to the martensitic phase. Addition of other alloying additions was not expected to affect the XRD peaks and the same has been reflected in the graphs.

Table 2: Identified XRD peaks in quenched samples

\begin{tabular}{|c|c|c|c|c|c|c|c|c|c|c|}
\hline \multicolumn{11}{|c|}{ IDENTIFIED PHASES } \\
\hline A-IN THE & $\mathrm{Cu}$ & $\mathrm{AlCu}$ & $\mathrm{AlCu}_{3}$ & & & & & & $\underline{\mathrm{Mn}}$ & $\mathrm{Al}$ \\
\hline AS CAST & & & & & & & & & & \\
\hline \multicolumn{11}{|l|}{ CONDITION } \\
\hline A & $\mathrm{Cu}$ & $\mathrm{AlCu}$ & $\mathrm{AlCu}_{3}$ & $\mathrm{Al}_{4} \mathrm{Cu}_{9}$ & & & & & & \\
\hline$A-Z n$ & $\mathrm{Cu}$ & $\mathrm{AlCu}$ & $\mathrm{AlCu}_{3}$ & & & & CuZn & & $\mathrm{Mn}$ & \\
\hline A-Si & $\mathrm{Cu}$ & $\mathrm{AlCu}$ & & $\mathrm{Al}_{4} \mathrm{Cu}_{9}$ & $\mathrm{Al}_{2} \mathrm{Cu}$ & $\mathrm{Cu}_{3} \mathrm{Al}_{2}$ & & $\mathrm{MnAl}_{6}$ & & \\
\hline A-Mg & $\mathrm{Cu}$ & $\mathrm{AlCu}$ & & $\mathrm{Al}_{4} \mathrm{Cu}_{9}$ & & $\mathrm{Cu}_{3} \mathrm{Al}_{2}$ & & & & \\
\hline $\mathrm{A}-\mathrm{Cr}$ & $\mathrm{Cu}$ & $\mathrm{AlCu}$ & $\mathrm{AlCu}_{3}$ & $\mathrm{Al}_{4} \mathrm{Cu}_{9}$ & $\mathrm{Al}_{2} \mathrm{Cu}$ & & & $\mathrm{MnAl}_{6}$ & & \\
\hline
\end{tabular}

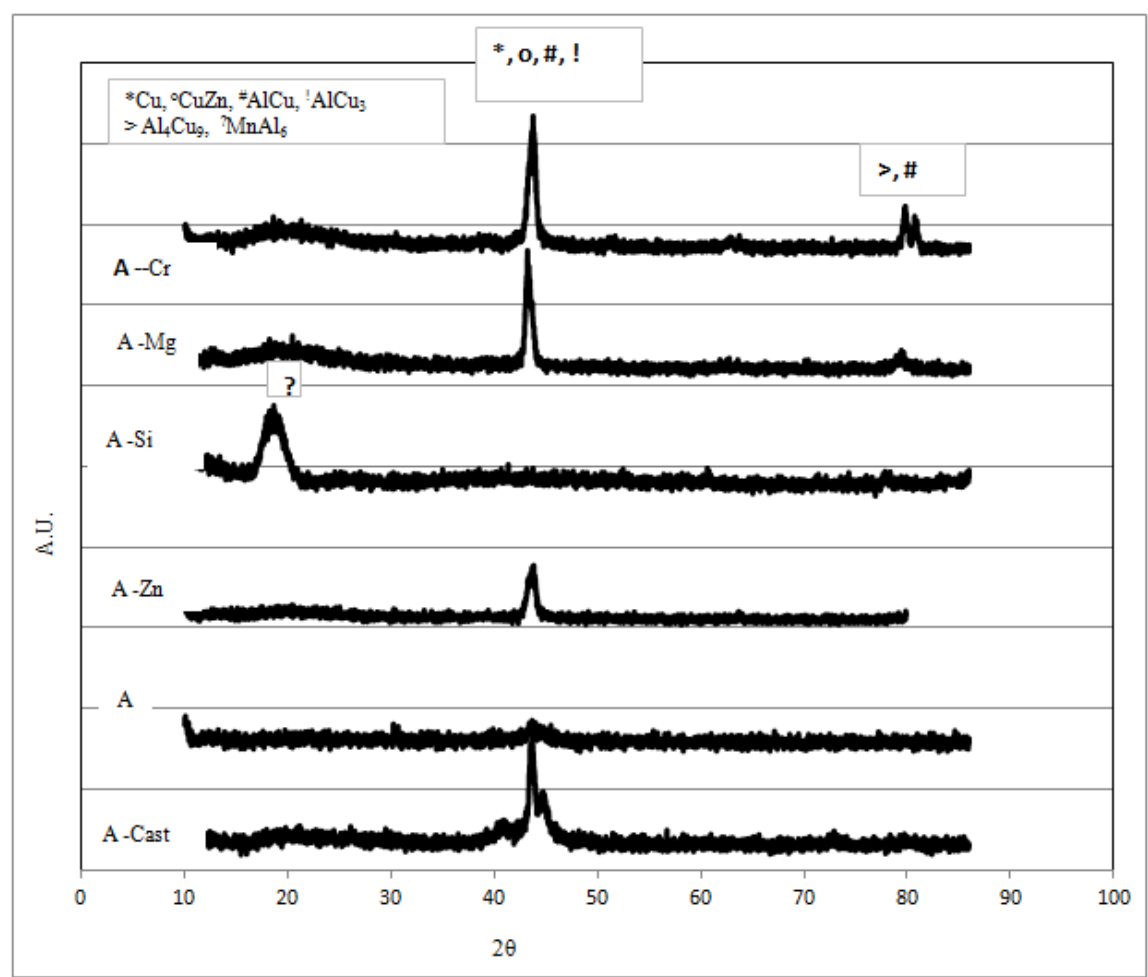

Figure 2: XRD pattern of quenched samples

The DSC studies for samples tested below room temperature upto $-10^{\circ} \mathrm{C}$ do not indicate any peaks [Figure 3]; hence the possibility of lower transformation temperatures in this class of alloys is ruled out. However, when the tests were carried out from room temperature to $600^{\circ} \mathrm{C}$, the DSC results indicate clear transformation peaks in all the samples; however the peaks are stronger in some and relatively blunt in the others [Figure 4]. The transformation temperatures are tabulated in Table 3. The temperature ranges overlap in most of the cases. Significantly high transformation temperatures have been recorded in $\mathrm{Cu}-\mathrm{Al}-\mathrm{Mn}$ alloys than conventionally reported $[\underline{8}, \underline{20}]$ except with the addition of $\mathrm{Mg}$ in which case no distinct peaks have 
been recorded which could be designated to the martensitic-austenite transformations. The endoscopic transformation observed in the case of $\mathrm{A}-\mathrm{Mg}$ is probably due to some other phase transformations; but these cannot be considered as martensitic-austenite transformations as the peak in the cooling cycle has been recorded at a higher temperature as compared to the peak in the heating cycle. The range of martensite retention is the maximum in ternary $\mathrm{Cu}-\mathrm{Al}-\mathrm{Mn}$ alloys [Sample A]; addition of quaternary elements decreases this range significantly. This means that whereas the alloys without quaternary additions would be better suited for its shape memory properties, ternary alloys would be better suited for higher transition temperatures.

Table 3: Transformation Temperatures of the alloys

\begin{tabular}{|c|c|c|c|c|}
\hline Alloy & As $\left[{ }^{\circ} \mathrm{C}\right]$ & Af $\left[{ }^{\circ} \mathrm{C}\right]$ & Ms [ $\left.{ }^{\circ} \mathrm{C}\right]$ & Mf $\left[{ }^{\circ} \mathrm{C}\right]$ \\
\hline A & 490 & 520 & 510 & 460 \\
\hline$A-Z n$ & 480 & 510 & 500 & 460 \\
\hline $\mathrm{A}-\mathrm{Si}$ & 490 & 510 & 505 & 475 \\
\hline $\mathrm{A}-\mathrm{Mg}$ & 260 & 335 & 540 & 525 \\
\hline $\mathrm{A}-\mathrm{Cr}$ & 460 & 500 & 490 & 470 \\
\hline
\end{tabular}
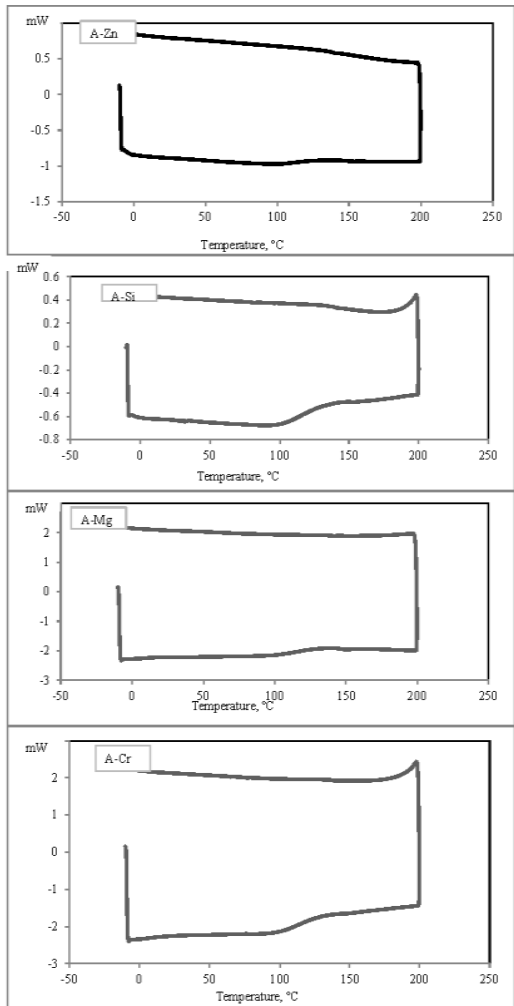

Figure 3: DSC of samples from $-10^{\circ} \mathrm{C}$ 

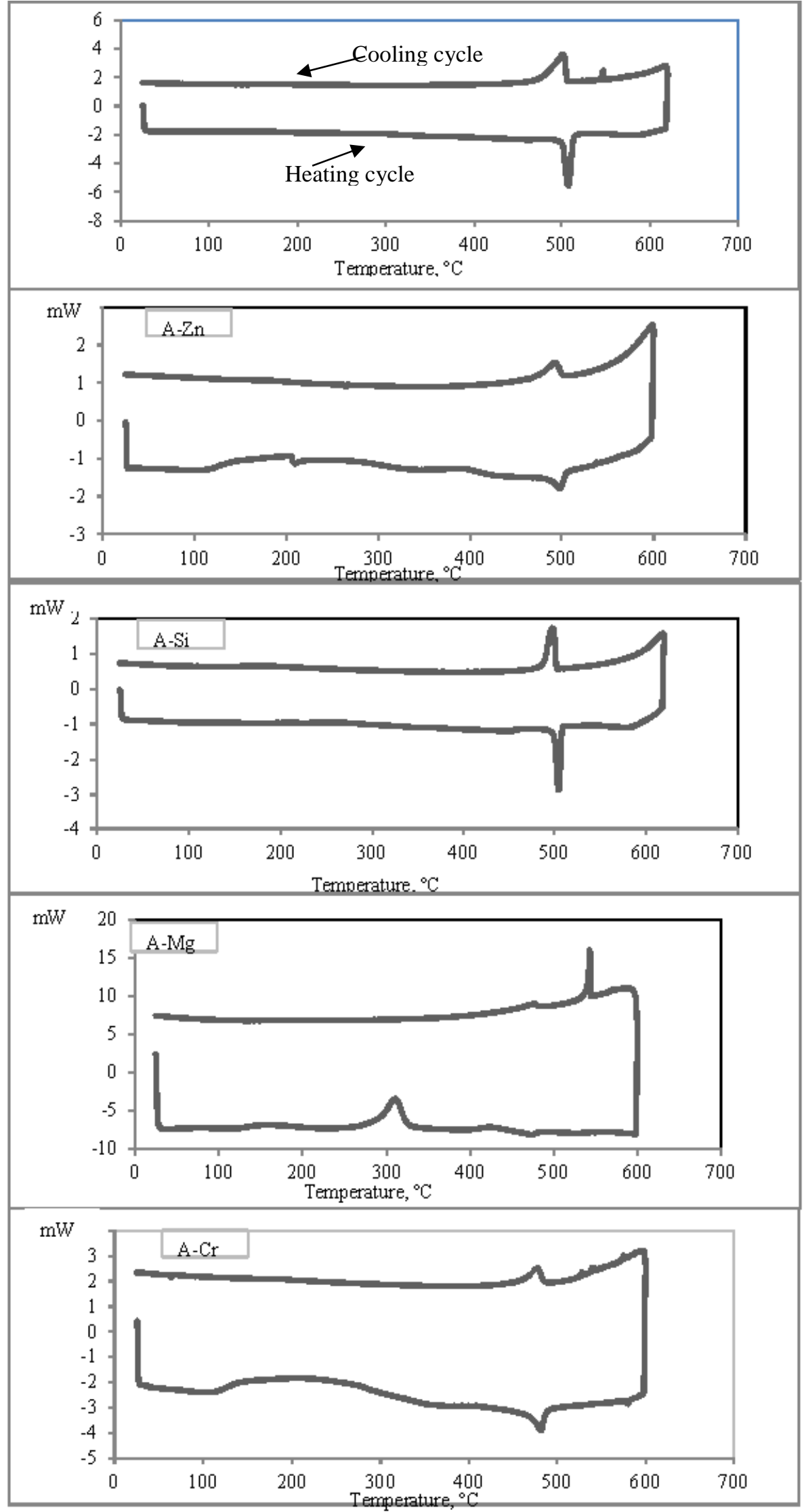

Figure 4: DSC of samples from room temperature 
The hardness of the samples is plotted in Figure 5; it is seen that additions in general increase the hardness; maximum increase over the base alloy is on adding $\mathrm{Cr}$ and the minimum on adding $\mathrm{Mg}$. further, quenching marginally decreases the hardness except for the base alloy where it remains stable. The decrease in hardness on quenching is attributed to the decreased hardness of the martensite phase.

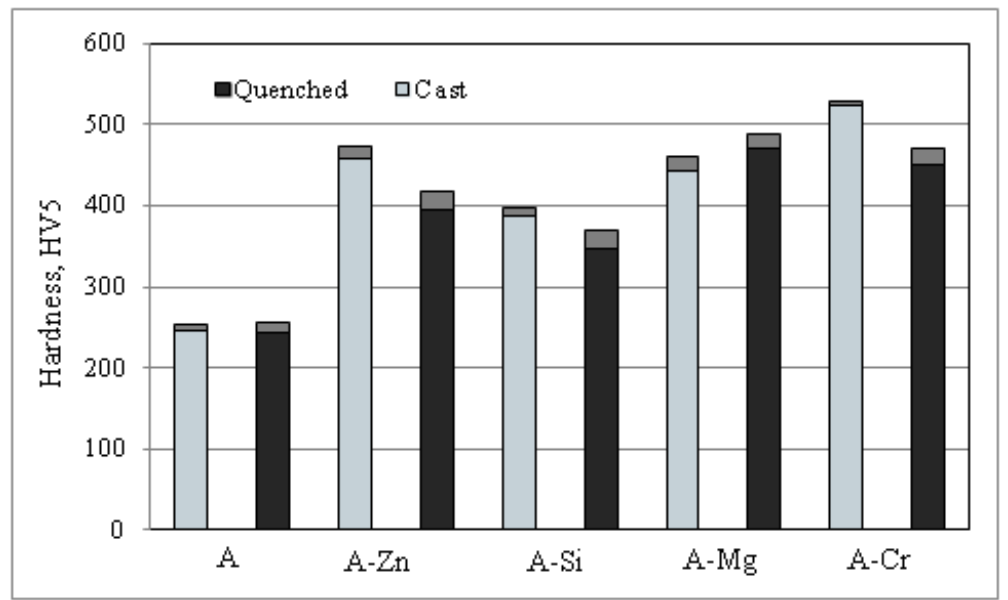

Figure 5: Hardness of samples in different conditions

\section{CONCLUSIONS}

Grain structure with $\alpha+\beta$ phases is visible in the homogenised condition of all the alloys; which is a pre requisite for martensite formation on quenching indicating that all the alloys have potential to exhibit the shape memory behaviour. The martensite formation is observed in most of the quenched samples however with different morphologies. The precipitated martensite phase is the plate- or spear-like martensite [the zigzag $\beta$ ' phase] is observed.

The martensitic phases of $\mathrm{Al}_{2} \mathrm{Cu}_{3}\left[\beta^{\prime}\right], \mathrm{Al} 4 \mathrm{Cu} 9$ [ $\left.\gamma^{\prime}\right]$ and $\mathrm{Cu}-\mathrm{Zn}$ have been clearly identified in the XRD patterns of the quenched samples. In some samples only martensitic phases have been identified in the quenched condition signifying perhaps completion to the martensitic phase.

The DSC studies for samples tested below room temperature upto $-10^{\circ} \mathrm{C}$ do not indicate any peaks; hence the possibility of lower transformation temperatures in this class of alloys is ruled out. However, when the tests were carried out from room temperature to $600^{\circ} \mathrm{C}$, the DSC results indicate clear transformation. Significantly high transformation temperatures have been recorded in the alloys. The range of martensite retention is the maximum in ternary $\mathrm{Cu}-\mathrm{Al}-\mathrm{Mn}$ alloys and addition of quaternary elements decreases this range significantly. This means that whereas the alloys without quaternary additions would be better suited for its shape memory properties, ternary alloys would be better suited for higher transition temperatures.

\section{ACKNOWLEDGMENTS}

The authors are thankful to CSIR, New Delhi for sponsoring the project on 'Design and Development of Thermo Responsive \& Magnetic Shape Memory Materials and Devices for Engineering Applications' under its 12th Five Year Plan to CSIR, AMPRI Bhopal under which the related activities were carried out; a part of the findings have been reported in the present paper. Project Fellows are thankful to CSIR, New Delhi for granting their fellowship under the project. Authors acknowledge with gratitude the contribution of Dr. V. Sampath, Professor, Metallurgical Engineering Department, IIT Chennai for extending the melting facilities at his disposal for synthesizing some of the alloys which have been dealt with in this paper. 


\section{BIBLIOGRAPHY}

[1] MA, J., KARAMAN, I. and NOEBE, R. D., "High temperature shape memory alloys", International Materials Reviews, v. 55, n.5, pp. 257-315, Sep. 2010.

[2] SARI, U. and KIRINDI, T., "Effects of deformation on microstructure and mechanical properties of a $\mathrm{Cu}$ Al-Ni shape memory alloy", Material Characterization, v. 59, n. 7, pp. 920-929, Jul. 2008.

[3] MIKI, M., MAESHIRO,N., and OGINO, Y., "Effects of additional elements on the super plasticity of a Cu-14Al-3Ni shape memory alloy", Materials Transactions, JIM, v. 30, n. 12, pp. 999-1008, Dec. 1989.

[4] ZENGIN,R., "Microstructure and oxidation properties of a neutron-irradiated $\mathrm{Cu}-13.5 \mathrm{wt} \% \mathrm{Al}-4 \mathrm{wt} \% \mathrm{Ni}$ shape memory alloy", Physica B, v. 363, n. 1-4, pp. 110-114, Jan. 2005.

[5] STANCIU, S., BUJOREANU, L.G., ÖZKAL, B., LUTFI ÖVEÇOĞLU, M. and SANDU, A.V., "Study of precipitate formation in $\mathrm{Cu}-\mathrm{Al}-\mathrm{Ni}-\mathrm{Mn}-\mathrm{Fe}$ shape memory alloys", Journal of Optoelectronics and Advanced Materials, v. 10, n. 6 pp. 1365-1369, Jun. 2008.

[6] MORRIS, M.A., "High temperature properties of ductile $\mathrm{Cu}-\mathrm{Al}-\mathrm{Ni}$ shape memory alloys with boron additions”, Acta Metall. V. 40, n. 7, pp. 1573-1586, Jul. 1992.

[7] ASANOVIC, V., DELIJIC K. and JAUKOVIC, N., "A study of transformations of $\beta$-phase in Cu-Al-Ni shape memory alloys”, Scripta Materialia, v. 58, pp. 599-601, Apr. 2008.

[8] BAKR, M. R., EL BATANOUNY, M.M. and ALI E. EL ASHRAM, "Microstructural characterization and solid state processing of $\mathrm{Cu}-\mathrm{Zn}-\mathrm{Al}$ shape memory alloy in a metal matrix composite", Canadian Journal on Mechanical Sciences and Engineering, v. 2, n. 2, pp. 11-18, Feb. 2011.

[9] MARUKAWA, K. and TSUCHIYA, K., "Two important aging effects on the martensite phase in Cu-ZnAl alloys: Rubber effect and stabilization of martensite”, J. Phys. IV France, v. 11, pp. 8-39, Nov. 2001.

[10] HOPUlElE, I., ISTRATE, S., STANCIU, S. and CALUGARU, G., "Comparative Study Of Certain Cu-Zn-Al-Type Alloys Concerning Their Superelastic Behavior And Shape Memory", Journal of Optoelectronics and Advanced Materials, v. 6, n. 1, pp. 277 - 282, Jan. 2004.

[11] BAI, Y., SHI, Q., GENG, G., SUN, D. and BIAN, X., "Formation mechanism of curved martensite structure in $\mathrm{Cu}$ based shape memory alloys", Journal of Materials Science and Technology, v. 16, n. 1, pp. 78-81, Jan. 2000.

[12] SEGUI, C., CESARI, E. and VAN HUMBEECK, J., "Irreversibility in two stage martensitic transformation of $\mathrm{Cu}-\mathrm{Al}-\mathrm{Ni}$ and $\mathrm{Cu}-\mathrm{Zn}-\mathrm{Mn}$ alloys", Materials Transactions, JIM, v. 31, n. 5, pp. 375-380, May 1990.

[13] SUTOU, Y., OMORI, T., KAINUMA, R. and ISHIDA, K., "Ductile Cu-Al-Mn based shape memory alloys: general properties and applications", Materials Science and Technology, v. 24, n. 8, pp. 896-90, Aug. 2008.

[14] LING-FEI, C., MING-PU, W., ZHOU, L., BEN, X. and YU-CHANG, S., "Thermal cycling effect in $\mathrm{Cu}-11.9 \mathrm{Al}-2.5 \mathrm{Mn}$ shape memory alloy with high Ms temperature", Transactions Nonferrous Society of China, v. 12, n. 4, pp. 716-719, Jul. 2002.

[15] CHEN, J., LIA, Z. and ZHAO, Y.Y., "A high-working-temperature CuAlMnZr shape memory alloy”, Journal of Alloys and Compounds, v. 480, n. 2, pp. 481-484, Jul. 2009.

[16] SUTOU, Y., KOEDA, N., OMORI, T., KAINUMA, R. and ISHIDA, K., "Effects of ageing on bainitic and thermally induced martensitic transformations in ductile $\mathrm{Cu}-\mathrm{Al}-\mathrm{Mn}$-based shape memory alloys", Acta Materialia, v. 57, n. 19, pp. 5748-5758, Nov. 2009.

[17] GUILEMANY, J. M., PEREGRÍN, F., LOVEY, F.C., LORCA, N. L. AND E. CESARI, “TEM study of $\beta$ and martensite in $\mathrm{Cu}-\mathrm{Al}-\mathrm{Mn}$ shape memory alloys", Materials Characterization, v. 26, n. 1, pp. 23-28, Jan. 1991.

[18] MALLIK, U.S. AND SAMPATH, V., "Effect of alloying on microstructure and shape memory characteristics of $\mathrm{Cu}-\mathrm{Al}-\mathrm{Mn}$ shape memory alloys", Materials Science and Engineering A, v. 481-482, pp. 680-683, May 2008.

[19] ZENGIN, R. AND CEYLAN, M., "The changes in transformation temperatures under stress of $\mathrm{Cu}$ 12.7Al-5Ni-2Mn alloys”, Thermochimica Acta, v. 414, n. 2, pp. 155-158, May 2004.

[20] MALLIK, U.S. and SAMPATH, V., "Influence of quaternary alloying additions on transformation temperatures and shape memory properties of $\mathrm{Cu}-\mathrm{Al}-\mathrm{Mn}$ shape memory alloy", Journal of Alloys and Compounds, v. 469, pp. 156-163, Feb. 2009. 
[21] WANG, Q., HAN, F., CUI, C., BU, S.and BAI, L., "Effect of aging on the reverse martensitic phase transformation behaviours of $\mathrm{Cu}-\mathrm{Al}-\mathrm{Mn}$ shape memory alloys", Materials Letters, v. 61, n. 30, pp. 51855187, Dec. 2007.

[22] OTSUKA, K. and REN, X., "Martensitic Transformation in Non Ferrous Shape Memory Alloys", Materials Science and Engineering A, v. 273-275, pp. 89-105, Dec. 1999. 